\title{
Stress of Students and Social-Pathological Phenomena
}

\author{
Jana Hanuliaková - Lívia Hasajová - Dáša Porubčanová ${ }^{*}$
}

DOI: $10.1515 /$ atd-2016-0023

\begin{abstract}
In the contribution, we focus on the social, emotional and behavioural factors of students' stress and their influence on the occurrence of social-pathological phenomena. We analyse the statements of teachers who mention the preferences of occurrence of single elements of students' stress. In the interpretation of data, we search for statistical significances of selected variables - stress and its influence on the occurrence of social-pathological phenomena in the educational reality.
\end{abstract}

Key words: factors of stress, school environment, social-pathological phenomena.

\section{Introduction}

Scientific research of stress in various environments and connections dates back to the end of 1950's. Primarily, stress became the subject of research of psychological sciences. Stress has penetrated all spheres of human life and, thus, its research acquired an interdisciplinary dimension. It became the object of scientific research of biological sciences, social sciences, pedagogical and neurodidactic sciences.

Research of the stress was done by Hart and Cooper (2005) and Sonnentag (2009), who focused on work stress; manager's stress was described by Kentoš and Sláviková (2013) or Hrazdilová Bočková, Dohnanská, Hilčíková and Vaníčková (2016), Hrazdilová Bočková and Škoda (2015), Wilhelm, DewhurstSavellis and Parker (2000) or Kyriacou and Sutcliffe (1977) researched the stress

\footnotetext{
Jana Hanuliaková, Dubnica Institute of Technology in Dubnica nad Váhom, Dubnica nad Váhom, Slovakia; hanuliakova@dti.sk

Lívia Hasajová, Dubnica Institute of Technology in Dubnica nad Váhom, Dubnica nad Váhom, Slovakia; hasajova@dti.sk

Dáša Porubčanová, Dubnica Institute of Technology in Dubnica nad Váhom, Dubnica nad Váhom, Slovakia; porubcanova@dti.sk
} 


\section{Acta Technologica Dubnicae \\ volume 6, 2016, issue 3}

in the teaching profession and the stress of teachers as well as their strategies of coping with stress; Folkman and Lazarus (1980) concentrated on coping oriented on problems and coping oriented on emotions; Tobin, Holroyd, Reynolds and Kigal (1989) or Tobin and Griffing (1995) have created a hierarchic model of coping strategies; Balážová and Zahatňanská (2007) dealt with the perception of stress situation by university students in Slovakia; Mederiová (2001) aimed at secondary school students. Research undertaken in this sphere was analysed by Kyriacou. He states that, "American psychologists focused their attention on seeking the answer for what the main reasons of school stress are" (Kyriacou, 2005, p. 90).

Two most common phenomena were resonating in the results of several studies. Stress from fear (examining and tests) and stress from change (beginning of school attendance, starting or changing school, other school grade). In his research, Denscombe (2000) concentrated on the diagnosticd of the factors of stress of adolescents at the age of 15-16. On the sample of 1648 students, he found out that adolescents are mostly threatened by psychical stress that was most commonly associated with examining, testing during classes, or passing final examinations. Consequently, experts world-wide started to be interested in this issue. Melgosa (1998) observed anxiety of students related to written tasks in relation to the cognitive elements of stress. Kyriacou (2005) selected the relation between failure in written exams and the occurrence of students' selfconfidence as the objective of his studies.

Murberg (as cited in Kyriacou, 2005), based on his extensive study, grouped the sources of stress into four areas:

- pressure on achieving good school results,

- overload of schoolwork,

- problems with parents or teachers in connection with school,

- problems with children of the same age, with inclusion in social groups.

He declared that the fields defined by him are closely linked to psychosomatic symptoms (headache, pain of the spine, etc.).

The sources of school stress were similarly classified by Kim (2003). According to his findings, sources of stress are the following:

- fear of exigent work,

- students' fear of the future,

- concerns related to future education,

- study stress, problems with a particular subject. 


\section{Acta Technologica Dubnicae \\ volume 6, 2016, issue 3}

Kyriacou and Moutantzi (2003) decided to study everyday stress present in the common activities in the class and they gathered information on what students link everyday stress to:

- teachers' rebuke of undisciplined students,

- teachers' feedback on students' work with many errors,

- students' inability to answer the teacher's questions.

Analysis and research of stress require a theoretical grip. Nakonečný understands stress "on one hand as a certain external, mostly threatening situation. On the other hand, as the internal psycho-physiological consequence of this situation" (Nakonečný, 1998, p. 68). Vinay perceives stress as "events that usually cause reaction in the form of distress (bad stress), but sometimes also as a tense situation that leads to positive emotions. The expression is used in the sense of causing events (stressors), but also in the sense of the answers to these events (stress reactions)" (Vinay, 2007, p. 32). Janiš indicates as stress "such a change in the organism that in certain state of threat may cause a high pressure level, can disrupt the routine scheme of everyday actions, weaken mental productivity and cause subjective unpleasant states of affective exhaustion" (Janiš, 2008, p.18).

While under the expression "stress" we understand internally difficult, heavy situations; those incentives, conditions or circumstances that have an effect on individuals and bring them to unfavourable situations are known as "stressors" (Křivohlavý, 1994). Cungi states that „stressors are situations to which individuals are exposed and in order to face them, have to adapt to them" (Cungi, 2001, p. 20). Rule and Nesdale divide stressors into "those primary, i.e. those that affect the organism directly, and those secondary that bring obstacles during an activity" (Nesdale, 1974, p. 68). For example, we can also divide stress into physical and emotional stress. Also, social stressors or individuals' health have an important role. These stressors influence each other also jointly. The influence of stress on an individual is not necessarily of a negative character. According to its effect on a person, we divide it into (as it is cited in Vinay, 2007):

- distress - stress with a negative effect,

- $\quad$ eustress - stress with a positive effect.

When students are not able to manage situations anymore, when they feel overloaded, they lose certitude and a detached view, they are in distress. The negative stress of students may be caused by the break-up of the family, feeling lonely, negative thoughts and visions, pain, disease, time deficit, low selfrealization, lack of prerequisites to manage their studies, etc. 


\section{Acta Technologica Dubnicae \\ volume 6, 2016, issue 3}

Eustress is linked to overcoming obstacles, with positive and pleasant expectations. It shows up in situations which we have under control.

According to Ďurdiak (2001), distress and eustress have similar physical manifestations. From the point of view of health, the level of stress and frequency in which it shows up are important. It becomes harmful when a certain individual limit is crossed and it also depends on the fact how strong the stress experienced by man is and how often it appears.

Kuric (1992) considers as the most important stress factors of students:

- preparation for a profession and the selection of a profession,

- accepting changes of body construction,

- acquiring addictions,

- love, sexuality and preparation for marriage, family life,

- problems with forming their own personality,

- taking the right attitude,

- problems in social relationships,

- other serious problems (traumas or other significant and unfavourable events).

For this period, Melgosa (1998) indicates the following possible stress factors:

- continuing with education,

- leaving parents' house,

- intimate relationships with the opposite sex,

- conclusion of the marriage,

- planning of the family,

- birth of children,

- professional growth,

- unemployment.

The study by Gabrhelová, Hilčíková and Dohnanská (2015) dealing with stress analysis in the process of university quality management or the paper by Tamášová and Barnová (2011) aimed at school climate as the determinant of the relationship between the level of students' resilience and school satisfaction bring very interesting results.

In light of the mentioned facts, in the empirical part, we focus on research of stress in school conditions.

When assessing stress and stress factors at school, it is necessary to investigate, to diagnose, to analyse, to evaluate and to propose possible solutions of 
elimination. Classification of starters of stress is evaluated by teachers and students in a different way.

In the research, we aimed at two dimensions under evaluation of stress by teachers. We focus our attention on the investigation of sources of stress of high school students (starters, stressors) through statements of teachers, and we indicate the results of an experimental research made in conditions of high schools.

\section{Methodological investigation of the issue in question}

We have differentiated investigation of stress and pathological phenomena into three fields:

- within the first part, we were investigating and making diagnostics of high school students' stress factors and determinants,

- in the second part, we made a long-term experimental research in the selected field of research,

- with the intention of recommendations for pedagogical practice, we have focused on programs of elimination of stress from the point of view of teachers' support of students when dealing with social-emotional symptoms.

The objective of the research was to identify and classify the stressors, stress situations that are involved in formation of social-pathological phenomena in high schools. Within the framework of the experimental group, we have eliminated stress factors and we have consequently evaluated the occurrence of social-pathological phenomena.

The main methods of realisation of the empirical investigation were a questionnaire of own construction, the method of experiment and the following statistical methods: F-test for equality of variances, two-sample t-test with unequal variance, nonparametric Wilcoxon signed-rank test (Mann-Whitney Utest), and descriptive statistics.

\section{Results}

We intended to find out about stressors and starters of students' stress at high schools through the questionnaire method with open items. In their statements, teachers addressed the stated examples and situations, evaluated by them as stressful for students.

We have processed framework groups based on the number of their occurrence. 


\section{Acta Technologica Dubnicae \\ volume 6, 2016, issue 3}

As the most frequent source of stress, examining and testing of knowledge of students are considered. The way teachers assess knowledge and the teachers' skills are evaluated as stressful. A significant number of teachers stated that students were stressed by oral testing, performing in front of the whole group of students and by project presentation.

Achieving positive results of the educational activity of teachers and learning of students is the primary objective of high school students. Aspects that put students under stress while achieving it are represented by bad grades, overloading through the quantity of assigned tasks, the quantity of written exams, fear from not managed schoolwork or school subjects. Teachers and their methodical-didactical approach are an important factor of education.

For high school students, teachers represent the starter of stress mainly through the placed demands, excessive authority, selective behaviour under which they do not treat students equally. Teachers influence students by a broad-scale of activities (motivation manner, quality of pedagogical communication, level of interactions, form and manner of mediation of housework, possibility of knowledge testing, evaluation manner, approach to students, respecting the principles, etc.).

In the context of stress experienced in school conditions, we have to make an appeal to the fact that in many cases it can develop into social-pathological phenomena and improper manifestation of behaviour. High school students most frequently experience bullying, aggressive behaviour, alcohol, smoking, drugs and the contemporary phenomenon of cyber-bullying.

Also, aggressive classmates are mentioned as a significant stress element for students. The occurrence of stress in school conditions often leads students to thefts as well as to truancy. An important part of the quality of students' life at school is positive experiencing of interactions in the class on the teacher-student, student-student and student-group levels. Students' social competences must be appreciated in every activity within the educational framework as well as during the events organised by school. For high school students, their inability to become integrated in a social group is perceived as the most stressful. Ridiculing and derision from the classmates is perceived by students very sensitively as a significantly stressful factor.

Teachers also consider stressful factors the following: bad group, superior classmates, students' complexes, performance in front of the class, no friends. From the point of view of students' personalities, stressors are failure, disinterest in studies, schoolwork and weak social family environment. 


\section{Acta Technologica Dubnicae \\ volume 6, 2016, issue 3}

\section{Discussion}

An analysis and investigation of the occurrence of stress situations and the starters of students' stress in the conditions of schools require to process the possible proposals on the elimination of stress factors that negatively influence the performance of students, their success, as well as the educational demonstrations of behaviour. Being able to make diagnostics, describe and verbalize what is stressful for students requires the adoption of skills that will help students to achieve that.

In psychological literature, dealing with stress is named coping (Křivohlavý, 2001). Under this expression, we understand intra-psychic, but also intentional effort to manage, tolerate, and reduce internal and external prerequisites placed on individuals. Those prerequisites are particularly high, they put people under stress and burden considerably or they exceed the resources that they have at their disposal (Křivohlavý, 1994).

There are more classifications and categorizations of coping behaviour or coping strategies. There is a vast amount of literature on the similarities and differences of women and men experiencing (close) relationships and using different strategies of coping with daily stress and significant life events. Western psychology expects women to be generally more anxious and men to be more avoidant while solving close-relationship conflicts and experiences in long term relationships. Rozvadský Gugová and Heretik (2011) used the Experiences in Close Relationships-Revised (ECR-R) questionnaire that is based on the Attachment-style theory that suppose four distinct attachment styles - secure, anxious/ambivalent, disoriented/disorganized and avoidant. Based on more classifications of coping strategies and their orientation, this division is currently steady according to Stuchlíková (2005):

- orientation on problem solving,

- orientation on dealing with emotions,

- escape reactions - escape, avoiding written exams, taking calming substances, negation of incurred situations, etc. Compared to the two previous reactions, this type of a reaction is only rarely adaptive.

Among these coping strategies, we put also religion, mental tension, acceptance, searching of instrumental, social or emotional support, behavioural tension, humour, use of alcohol and drugs, planning of problem solving, active coping, coping by suppressing, taking attention away, retreat, self-criticism, confrontational way of coping with stress, accusing the others, searching for the positive sides of an event, taking personal responsibility for solving a situation, self-control, an attempt to avoid stress situations and to escape, resignation, 


\section{Acta Technologica Dubnicae \\ volume 6, 2016, issue 3}

monitoring (tendency to search for information on threats), etc. Thus, coping strategies represent certain ways of behaviour in various load situations. Several authors dedicated their work to investigation of resources for stress reduction in the context of different variables (sex, personality, sense of life, etc.). Resources for stress reduction are addictive, trans-situational, relatively consistent patterns of coping on behavioural, cognitive or experience level, used by individual when meeting internal or external stressors (Ruiselová, 2006).

According to Gerbová (2011), the repertoire of ways of proper stress elimination includes:

- effective time management,

- social support,

- correct dietary habits,

- relaxation (yoga, Macháček's relaxing-activating method, Schultz's autogenic training, Jacobson's progressive relaxation, meditation, biofeedback, massages, fast relaxation techniques),

- art therapy, music therapy, dance and movement therapy,

- breathing exercises,

- positive thoughts, etc.

\subsection{Teachers in the process of stress elimination in the educational environment}

The ability of self-knowledge, self-control in interaction of relationships and environment represents a lifelong journey of personality development. Family is the source where we acquire the first skills in order to form our own identity. The school continues in this influence. As well as we cannot ensure "perfect" conditions for the social-emotional development of all the parents and families, also teachers have different levels of social-emotional competences. Since schools are professional institution, in the last years, many programmes and trainings for teachers focusing on the development of students' social competences have been prepared.

Stress is a part of the life of individuals (teachers and students) in the school environment. We think that the development of students in the area of soft-skills is a form of natural prevention for dealing with situations causing students' stress. In order to strengthen students' soft-skills, it is necessary to support and to dedicate attention to intervention by teachers.

\section{Conclusions}

The submitted paper presents a theoretical analysis of stress, stressors of high school students and the consequent empirical investigation. The objective was to analyse the most frequent reasons or starters of high school students' stress from 


\section{Acta Technologica Dubnicae \\ volume 6, 2016, issue 3}

the point of view of teachers. By comparing statements of teachers, we have processed the sequence of most frequently mentioned stressors of students. We have focused on searching for the mutual dependence of stress and socialpathological phenomena and the verification of the stated hypothesis. Diagnostics and evaluation of students' stress require the application of teachers' competences in a multispectral influence. After diagnostics and the consequent evaluation, the pedagogical reality requires teachers to work with students in order to eliminate and manage students' potential and real stress. There are more possibilities, programs, through which it is possible to work with difficult situations (stress).

\section{References}

Balážová, M., \& Zakut’anská, Z. (2007). Vnímanie zátažových situácii a spôsoby ich zvládania študentkami a študentmi vysokých škôl. Prešov: Prešovská Univerzita.

Cungi, Ch. (2001). Jak zvládat stres: Metódy a praktická cvičení. Praha: Portál.

Denscombe, M. (2000). Social conditions for stress. British Educational Research Journal, 26(3), 259-374.

Ďurdiak, L. (2001). Psychohygiena mladého človeka. Nitra: Enigma.

Folkman, S., \& Lazarus, R. S. (1980). An analysis of coping in a middleaged community sample. Journal of Health and Social Behavior, 21(3), 219-39.

Gabrhelová, G., Hilčíková, D., \& Dohnanská, M. (2015). Stress analysis in the process of university quality management. Journal on Law Economy \& Management. London: Eastern European Development, 5(2), 36-40.

Gerbová, M. (2011). Zvládanie redukcie stresu u študentov sociálnej práce. Retrieved from http://www.prohuman.sk/socialna-praca/zdrojeredukcie-stresu-u-studentov-socialnej-prace

Hart, P. E. \& Cooper, J. M. (2005). International Cooperative Ataxia Rating Scale (ICARS): appropriate for studies of Friedreich's ataxia? Retrieved from http://www.ncbi.nlm.nih.gov/pubmed/16114019

Hrazdilová Bočková, K., \& Škoda, M. Relation between teachers and students in the concept of school culture. Present Day Trends of Innovations (pp. 278 287). Wisla. Poland.

Hrazdilová Bočková, K., Dohnanská, M., Hilčíková, D., \& Vaníčková, R.. (2016). Project manager's competencies in Czech lottery industry enterprise. Economics World. 4(6).

Janiš, K. (2008). Učebni text k problematice rodinné a sexuální výchovy. Hradec Králové: Gaudeamus. Retrieved from http://toc.nkp.cz/NKC/200811/ contents/nkc20081818070_1.pdf

Kentoš, M., \& Sláviková, G. (2013). Zvládanie stresu manažérmi. Praha: Radix. 


\section{Acta Technologica Dubnicae \\ volume 6, 2016, issue 3}

Kim, S. H. (2003). Tisic a jeden způsob jak motivovat sebe $i$ druhé. Praha: Management Press.

Křivohlavý, J. (1994). Jak zvládat stres. Praha: Grada Avicenum.

Křivohlavý, J. (2001). Psychológie zdraví. Praha: Portál.

Kuric, J. (1992). Vývinová psychológia. Nitra: VŠPG.

Kyriacou, Ch. (2005). Řešeni výchovných problémů ve škole. Praha: Portál, 2005.

Kyriacou, Ch., \& Moutantzi, G. (2003). Pupil stress in the primary classroom in England and Greece. Education Today, 53, 44-46.

Kyriacou, Ch., \& Sutcliffe, J. (1977). A model of teacher stress. Educational Studies, 4(1), 1-6.

Mederiová, T. (2001). Zvládanie stresu u stredoškolskej mládeže v SR. Retrieved from http://www.ruvzsn.sk/Zvladanie_stresu.pdf)

Melgosa, J. (1998). Zvládni svoj stres. Vrútky: Advent - Orion.

Nakonečný, M. (1998). Základy psychológie. Praha: Académia.

Rozvadský Gugová, G., \& Heretik, A. (2011). Gender differences in attachment styles using Slovak version of the Experiences in Close RelationshipsRevised (ECR-R). Acta Technologica Dubnicae, 1(2), 29-36. doi: 10.1515/atd-2015-0043

Ruiselová, Z. et. al. (2006). Štýly zvládania zát’aže a osobnost'. Bratislava: Ústav experimentálnej psychológie SAV.

Rule, B. G., \& Nesdale, A. R. (1974). Children's Reactions to Information about the Intentions Underlying an Aggressive Act. Child Development, 45(3), 794-798.

Sonnentag, S. (2009). Current Perspectives on Job-stress Recovery. In Research in Occupational Stress and Well-being. Bingley: Emerald Group Publishing Limited.

Stuchlíková, I. et al. (2005). Zvládani emočných problému školáků. Praha: Portál.

Tamašová, V., \& Barnová, S. (2011). School climate as the determinant of the relationship between the level of students' resilience and school satisfaction. Acta Technologica Dubnicae, 1(1), 19-37. doi: 10.1515/atd2015-0037

Tobin, D. L., \& Griffing, A. S. (1995). Coping and depression in bulimia nervosa. International Journal of Eating Disorders, 18(4), 359-363.

Tobin, D. L., Holroyd, K. A., Reynolds, R. V., \& Kigal, J. K. (1989). The hierarchical factor structure of the Coping Strategies Inventory. Cognitive Therapy Resesearch, 13, 343-361.

Vinay, J. (2007). Stres a zdraví. Praha: Portál.

Wilhelm, K., Dewhurst-Savellis, J., \& Parker. G. (2000). Teacher stress? An analysis of why teachers leave and why they stay. Teachers and Teaching: Theory and Practice, 6, 291-304. 